\title{
makalah manajemen proyek sistem informasi
}

\author{
Muhammad Lubis Angsori \\ 175100026 \\ Universitas Mitra Indonesia,Sistem Informasi \\ muhammadlubisangsori.student@umitra.ac.id
}

\begin{abstract}
ABSTRAK
Kebijakan dan Perencanaan Proyek Sistem Informasi Suatu sistem informasi dapat dikembangkan karena adanya kebijakan dan perencanaan telebih dahulu. Tanpa adanya perencanaan sistem yangbaik, pengembangan sistem tidak akan dapat berjalan sesuai dengan yang diharapkan. Tanpa adanya kebijakan pengembangan sistem oleh manajemen

puncak, maka pengembangan sistem tidak akan mendapat dukungan dari manajemen puncak tersebut.
\end{abstract}

\section{PENDAHULUAN}

\subsubsection{Dasar-Dasar Organisasional}

Organisasi adalah sistem yang saling mempengaruhi dan salaing bekerja sama antara orang yang satu dengan orang yang lain dalam suatu kelompok untuk mencapai suatu tujuan tertentu yang telah disepakati bersama.

Organisasi merupakan system maka terdiri dari beberapa elemen yaitu :

1. Orang, dalam organisasi harus ada sekelompok orang yang bekerja dan salah satunya ada yang memimpin organisasi tersebut.

2. tujuan, dalam organisasi harus ada tujuan yang harus dicapai, baik dalam jangka pendek maupun jangka panjang.

3. posisi, setiap orang yang ada dalam suatu organisasi akan menempati posisi atau kedudukannya masing-masing.
4. pekerjaan, setiap orang yang ada dalam organisasi tersebut mempunyai pekerjaan (job) masing-masing sesuai dengan posisinya.

5. teknologi, untuk mencapai tujuan organisasi membutuhkan teknologi untuk membantu dalam pengolahan data menjadi suatu informasi.

6. struktur, struktur organisasi merupakan pola yang mengatur pelaksanaan pekerjaan dan hubungan kerja sama antar setiap orang yang ada dalam organisasi tersebut.

7. lingkungan luar, merupakan elemen yang sangat penting dan akan mempengaruhi keberhasilan suatu organisasi, misalnya adanya kebijakan pemerintah tentang organisasi. 
Prinsip-prinsip organisasi adalah nilai-nilai yang digunakan sebagai landasan kerja bagi setiap orang yang ada dalam organisasi tersebut untuk mencapai keberhasilan tujuan yang telah disepakati. Prinsip-prinsip yang ada dalam organisasi meliputi :

1. Tujuan organisasi yang jelas

2. Tugas yang dilakukan harus jelas

3. Pembagian tugas yang adil

4. Penempatan posisi yang tepat

Adanya koordinasi dan integrasi Manajemen dalam organisasi terdiri dari tiga tingkatan pembuat keputusan manajemen yaitu : manajemen tingkat bawah (operasional), manajemen tingkat menengah (perencanaan dan kontrol manajerial) dan manajemen tingkat atas(strategik). Setiap level memiliki tanggung jawabnya sendiri-sendiri dan semuanya bekerja sama dalam mencapai tujuan dan sasaran.

\section{Manajemen tingkat bawah (operasional)}

- $\quad$ Manajer operasional membuat

keputusan berdasarkan aturan-aturan yang telah ditetapkan sebelumnya dan menghasilkan hal-hal yang dapat diprediksikan bila diterapkan dengan benar.

- $\quad$ Manajer operasi adalah pembuat

keputusan yang pekerjaannya lebih jelas sehingga dapat mempengaruhi implementasi dalam jadwal kerja, kontrol inventaris, penerimaan, dan pengontrolan prosesproses seperti produksi.
- $\quad$ Manajer operasi membutuhkan

informasi internal yang repetitif, dan sangat tergantung pada informasi yang memuat tentang kinerja terbaru dan merupakan pengguna on-line terbesar, sumberdayasumberdaya informasi real-time

2. Manajemen tingkat menengah (perencanaan dan kontrol manajerial)

- $\quad$ Manajer tingkat menengah membuat perencanaan jangka pendek dan mengontrol keputusan-keputusan tentang bagaimana sumberdaya bisa dialokasikan dengan baik untuk memenuhi tujuan-tujuan organisasional, dan meramalkan kebutuhan-kebutuhan sumberdaya dimasa datang untuk meminimalkan problem-problem pegawai yang dapat membahayakan produktivitas.

- $\quad$ Manajer tingkat menengah sangat tergantung pada informasi internal dan membutuhkan sangat besar informasi real- time agar dapat melakukan pengontrolan dengan tepat dan informasi terbaru atas kinerja yang diukur sesuai standar.

3. Manajemen tingkat atas (strategik)

- Manajer strategik membuat keputusankeputusan yang akan membimbing 
manajer operasional dan manajer tingkat menengah.

- $\quad$ Manajer strategik bekerja di lingkungan pembuat keputusan yang sangat tidak pasti. Membutuhkan informasi yang bersifat strategis, karena tugas kesehariannya adalah pengarahan dan perencanaan.

- Informasi yang strategis diperlukan untuk menilai tingkat keberhasilan organisasi menjalankan tugas dan tujuan organisasi.

- Membutuhkan informasi internal (agar bisa beradaptasi dengan perubahanperubahan yang terjadi dengan cepat) dan informasi eksternal (untuk mengetahui peraturan pemerintah,kebijakan perekonomian, kondisi pasar dan strategi perusahaan-perusahaan pesaing) SIM Kedudukan Sistem Informasi Manajemen (SIM) dalam pelaksanaan P2KP menempati posisi yang signifikan dan strategis mengingat fungsi utamanya yang akan mengelola seluruh data/informasi perkembangan maupun hasil-hasil pelaksanaan kegiatan P2KP di lapangan. Melalui SIM P2KP diharapkan akan menjadi sarana yang efektif untuk memonitoring dan mengevaluasi pelaksanaan serta hasil kegiatan proyek P2KP secara keseluruhan. Pada akhirnya, akurasi data serta informasi yang dihasilkan dari SIM P2KP tersebut diharapkan dapat menjadi bahan pertimbangan bagi pengambilan kebijakan dan keputusan stakeholders P2KP dalam rangka perbaikan dan upaya penyempurnaan kinerja proyek P2KP.
Tingkat validitas dan realibilitas SIM P2KP sangat bergantung kepada penerapan manajemen data di semua tingkatan pelaku, oleh karena itu untuk menjamin agar pengelolaan manajemen data di semua tingkatan termonitor dengan baik berikut disajikan hasil-hasil pengendalian manajemen data yang dilakukan oleh Tim SIM Pusinfo.

Greasoft Sebagai Perusahaan Pembangun Software Khusus Organisasi Nirlaba di Indonesia Web ini banyak menyediakan fasilitas dan perangkat yang dibutuhkan untuk membuat laporan keuangan pada organisasi nirlaba sejenis yayasan ataupun LSM (NGO) di Indonesia secara cepat dan mudah. Fasilitas download hanya diperuntukkan untuk member yang telah dikategorikan menurut kebutuhannya. Untuk mendownload PLAKON (Software Akuntansi khusus organisasi nirlaba, LSM (NGO) di Indonesia) terbaru silakan isi nama member dengan nama lembaga masing-masing untuk mendapatkan nomor registrasi download. "Untuk klien yang memakai SANGO (Software Accounting for Non Goverment Organization) kini software tersebut sudah kami tambah featurenya untuk mengikis segala problem keuangan yang anda hadapi dewasa ini, silakan kontak kami untuk kami kirimkan update SANGO terbaru. Semua ini kami berikan cumacuma sebagai wujud cinta kami kepada klien yang telah bekerjasama dengan baik dengan kami. Karena kami sadar beban anda sudah 
sangat berat dalam melayani kemajuan

masyarakat Indonesia, maka kami senantiasa

untuk selalu berusaha mempermudah dan

mengurangi beban pekerjaan anda. “

Adalah aplikasi akuntansi yang dikhususkan

untuk organisasi nirlaba di Indonesia. SANGO

terus berkembang hingga sekarang.

Selain kemudahan dalam penggunaan kelebihan

software ini adalah jurnal yang double entry tapi

berperilaku single entry dengan kolom yang

tetap memakai debet dan kredit juga akun yang

dapat di blok sesuai sumber dananya. Dalam

laporan yang tergolong proyek (Status Anggaran

dan Laporan Penerimaan dan Pengeluaran Dana)

dapat kita tampilkan berdasarkan jangka waktu

proyek tersebut.

Laporan yang dihasilkan SANGO :

- Buku Kas

- Buku Bank

- Buku Besar

- Sub Buku Besar

- Posisi Keuangan Lembaga

- Posisi Keuangan Perdonor

- Aktivitas Lembaga

- Aktivitas Perdonor

- Laporan Penerimaan dan Pengeluaran Dana

(per periode proyek)

- Status Anggaran

- Neraca Saldo

- Cash Flow (bulanan, tahunan, perdonor)

Semua laporan ini dapat dipreview atau diexport

kedalam Microsoft(R) Excel

Feature pengembangan pada SANGO 2.0 :

- Database Modulasi

- Multi data

- Otomatic Chart of Account (Coa Otomatis)

- Multi Bahasa

- Export import data

- Multi Currency

- Kemudahan dan fasilitas lainnya.

Komponen Pendukung Aplikasi :
- Greasoft Database Engine

- Greasoft virus protector

Greasoft Database Engine adalah komponen

buatan Greasoft yang berfungsi sebagai

tambahan kecepatan pada engine database

standar. Greasoft juga mengamankan

databasenya terhadap virus-virus yang

menyerang database dengan bantuan Greasoft

virus protector. Seiring perkembangan virus

yang kian hari kian beragam proteksi terhadap

virus akan diupdate jika ditemukan virus yang

menyerang database tersebut dan program tidak

mengenalinya.

\section{PEMBAHASAN}

\subsubsection{Kebijakan Sistem}

Kebijakan untuk mengembangkan sistem informasi dilakukan oleh manajemen puncak karena manajemen menginginkan untuk meraih kesempatan-kesempatan yang ada yang tidak dapat diraih oleh sistem yang lama atau sistem lama mempunyai kelemahan (masalah).

\subsubsection{Perencanaan Sistem}

Perencanaan sistem menyangkut estimasi sumberdaya (kebutuhan- kebutuhan fisik dan tenaga kerja) dan biaya. Perencanaan sistem terdiri dari : perencanaan jangka pendek (periode 1-2 tahun) dan jangka panjang (periode sampai 5 tahun). Perencanaan sistem biasanya ditangani oleh staf perencanaan sistem, departemen 
pengembangan sistem atau depertemen

pengolahan data.

\subsubsection{Proses Perencanaan Sistem}

Proses perencanaan sistem dapat dikelompokkan dalam tiga proses utama, yaitu :

$\S$ Merencanakan proyek-proyek system

Tahapan proses perencanaan sistem yaitu :

Mengkaji tujuan, perencanaan strategi dan taktik perusahaan Mengidentifikasi proyek-proyek system Menetapkan sasaran proyek-proyek system Menetapkan kendala proyek-proyek sistem (mis. Batasan biaya, waktu, umur ekonomis, peraturan yang berlaku) Menetukan prioritas proyek-proyek sistem

Membuat laporan perencanaan system Meminta persetujuan manajemen

$\S$ Mempersiapkan proyek-proyek sistem yang akan dikembangkan

Persiapan ini meliputi :

Menunjuk team analis (dapat berasal dari

departemen pengembangan

yang ada atau dari luar perusahaan

(konsultan) Mengumumkan proyek pengembangan system.

$\S$ Mendefinisikan proyek-proyek sistem yang dikembangkan Melakukan studi untuk mencari alternatif pemecahan terbaik yang paling layak untuk dikembangkan. Tahapan yang dilakukan yaitu :
Mengidentifikasi kembali ruang lingkup dan sasaran proyek sistem

Melakukan studi kelayakan Menilai kelayakan proyek system Membuat usulan proyek systemMeminta persetujuan manajemen III_Manajemen Proyek Sistem Informasi.

\subsection{Perkiraan Proyek Sistem Informasi}

Sekarang biaya merupakan elemen yang paling penting dan mahal dalam pengembangan sistem berbasis komputer. Perkiraan biaya yang salah atau kurang tepat dapat mengurangi keuntungan atau malah kerugian. Perkiraan biaya sistem informasi dan usaha tidak dapat dihitung dengan tepat, karena banyak variabel (manusia, teknikal, lingkungan) yang mempengaruhinya. Untuk mencapai perkiraan biaya dan usah yang dapat diandalkan, digunakan pilihan sebagai berikut : Memperkirakan waktu yang paling lama dari pengerjaan proyek Perkiraan berdasarkan pada proyek yang sama

Menggunakan teknik dekomposis Menggunakan satu atau lebih model empiris

Memperkirakan waktu untuk menyelesaikan setiap kegiatan merupakan bagian yang paling sulit, untuk itu butuh pengalaman dalam memperkirakan waktu yang diperlukan. Penjadwalan tugas-tugas (kegiatan) dapat menggunakan :

1. Grafik Gantt Merupakan suatu grafik dimana ditampilkan kotak-kotak yang mewakili setiap 
tugas(kegiatan) dan panjang masing-masing

setiap kotak menunjukkan panjang

relative tugas-tugas yang dikerjakan.

2. Diagram PERT (Program Evaluation and

Review Techniques)

Suatu program (proyek) diwakili dengan jaringan simpul dan tanda panah yang

kemudian dievaluasi untuk menentukan

kegiatan-kegiatan terpenting, meningkatkan

jadwal yang diperlukan dan merevisi kemajuan-

kemajuan saat proyek telah

dijalankan. Diagram PERT lebih baik dari Gantt,

karena :

- Mudah mengidentifikasi tingkat prioritas

- Mudah mengidentifikasi jalur kritis dan kegiatan-kegiatan kritis

- Mudah menentukan waktu kendur

3. Penjadwalan proyek berbasis computer menggunakan PC untuk membuat jadwal proyek lebih praktis dan menguntungkan.

Contoh program penjadwalan yaitu Ms Project,

Symantec's Timeline dan Computer

Associates' CA-Super Project. Proses

pengembangan sistem informasi (PL)

dikembangkan oleh pelaku-pelaku yang dapat

dikatagorikan dalam 5 kelompok :

1. Manajer senior, yang bertugas mendefinisikan

permasalahan-permasalahan bisnis

dan sangat berpengaruh pada proyek tersebut.

2. Manajer proyek (teknik), yang merencanakan, memotivasi, mengorganisasi dan mengontrol orang-orang yang bekerja dalam proyek tersebut (praktisi).
3. Praktisi, adalah orang yang mempunyai kemampuan teknis yang dibutuhkan untuk mendapatkan produk sistem informasi (program aplikasi).

4. Pelanggan, adalah orang yang membutuhkan sistem informasi (PL) tersebut.

5. Pengguna akhir, orang yang berinteraksi dengan sistem informasi (PL) yang dikaitkan dengan penggunaan produk Aspek Rekayasa Perangkat Lunak dalam Media Pembelajaran "Waduh kok softwarenya nggak mau jalan ..." "Lho kok proses instalasinya sulit sekali ..." Itu mungkin keluhan yang sering kita dengar ketika kita menggunakan sebuah software atau perangkat lunak di komputer kita. Dan bukan sesuatu yang mustahil, kemungkinan besar terjadi juga di perangkat lunak media pembelajaran yang kita kembangkan. Jangan dilupakan bahwa media pembelajaran yang terdiri dari media presentasi pembelajaran (alat batu guru untuk mengajar) dan software pembelajaran mandiri (alat bantu siswa belajar mandiri) adalah juga suatu perangkat lunak. Baik tidaknya sebuah perangkat lunak, biasanya menunjukkan bagaimana kualitas perangkat lunak tersebut, hal ini sudah kita kupas tuntas di artikel tentang pengukuran perangkat lunak. Nah, media pembelajaran yang baik adalah yang memenuhi parameter-parameter berdasarkan disiplin ilmu rekayasa perangkat lunak, seperti pada contoh diatas (efisiensi, reliabilitas, usabilitas, dsb). 
Setelah aspek dan penilaian media pembelajaran kita bahas, artikel ini akan fokus di satu sisi penilaian yaitu aspek rekayasa perangkat lunak. Bagaimanapun juga saya tetap bersandar ke standard pengukuran perangkat lunak (baik ISO standard maupun best practice) pada saat menyusun kriteria-kriteria penilaian. Saya modifikasi sesuai dengan kebutuhan dan supaya lebih mudah dipahami oleh peserta lomba. Kriteria penilaian dalam aspek rekayasa perangkat lunak yang akhirnya disetujui dalam diskusi di tim penyusun (LIPI, Pustekkom, IlmuKomputer.Com) adalah seperti di bawah:

\section{Efektif dan Efisien dalam Pengembangan}

Maupun Penggunaan Media Pembelajaran

“Kok lambat yach?” "Petunjuk Pemakaian: matikan seluruh program lain, karena program ini perlu memory $1 \mathrm{~GB}$ untuk dapat dijalankan" "Program besar sekali, menghabiskan space di komputer!" Seringkali sebuah program yang sepertinya berukuran kecil dan memiliki fitur yang tidak terlalu rumit, tetapi berjalan sangat lamban. Kalau seandainya saja setiap komputer memiliki kecepatan yang tidak terbatas dan memory (RAM) yang bebas tidak terbatas, maka tentu tidak akan menjadi masalah. Tetapi setiap komputer memiliki kecepatan terbatas, memory (RAM) terbatas dan kapasitas penyimpanan tetap (hardisk) terbatas. Oleh karena itu, penting untuk mengatur pemakaian resource (CPU, RAM dan hardisk) tersebut secara efektif dan efisien. Kelambatan, rendahnya respon dan throughput biasanya terjadi karena pembuat tidak memikirkan efesiensi sumber daya yang terserap oleh program. Misalnya untuk pemakaian gambar-gambar yang ditampilkan dalam ukuran kecil, pembuat tetap menggunakan gambar asli yang beresolusi tinggi, tidak melakukan usahausaha kompresi dan pemotongan yang tepat. Sebaliknya, ada pula gambar yang seharusnya memakai resolusi tinggi, tetapi digunakan gambar yang beresolusi rendah.

Hal lain yang memungkinkan tidak efisiennya pemakaian resource adalah penggunaan algoritma yang kurang tepat Misalnya untuk pekerjaan pengurutan (sorting) sebuah kumpulan data, pembuat tidak memanfaatkan algoritmaalgoritma sorting yang terkenal efektif seperti: insertion-sort, merge-sort dan lain-lain. Misalnya ada komputer A dengan kecepatan 100 kali lebih cepat dari komputer B, yang menjalankan algoritma yang berbeda untuk masalah yang sama. Kalau kita dapat memilih algoritma yang lebih tepat dan efisien di komputer B, maka program dapat saja berjalan lebih cepat $10 \mathrm{kali}$ lipat di komputer B.

Salah satu kasus yang sering muncul adalah, karena terlalu bersemangat, pembuat media pembelajaran, menampilkan semua pustaka gambar yang ia miliki dan efek-efek animasi dan simulasi yang ia kuasai ke dalam media pembelajaran, meskipun mereka tidak terlalu penting dan efektif dalam membantu proses 
pembelajaran.

2. Reliabilitas (Kehandalan) Murid: Pak, program ini kok sering hang ya?

Guru: Kenapa? Kapan errornya? Murid: Gak tahu, tidak ada pesan error tuh.

Program dikatakan reliable atau handal bila program dapat berjalan dengan baik, tidak udah hang, crash atau berhenti pada saat pengoperasian. Kehandalan program juga dinilai dari seberapa jauh dapat tetap berjalan meskipun terjadi kesalahan pada pengoperasian (error tolerance). Pengguna memerlukan feedback sesuai dengan kondisi system (termasuk berapa lama pengguna harus menunggu, dll).

3. Maintainabilitas (Dapat Dipelihara/Dikelola dengan Mudah)

"Good software is maintainable" (Reinhard Miller) "It looks obvious until you try it" (IEEE Software)"Programming is like poetry. It conveys a message, not only to the computer, but to those who modife and use your program" (Jonathan Bartlett)

Struktur program disusun dengan algoritma, alur penyajian, pengorganisasian, dan keterkaitan antar bagian sehingga mudah dalam modifikasi. Kode atau script tetap sederhana dan mudah dipahami meskipun menjalankan fungsi yang kompleks. Kode bersifat modular dengan dokumentasi pada tiap bagian yang memudahkan dalam modifikasi dan perubahan (maintenance).

Sehingga siapa saja yang ingin

merubah/memperbaiki/menambah fitur program dapat dengan mudah melakukannya. Selain penambahan fitur, hal yang sering dilakukan oleh programer adalah menemukan bug dalam programnya. Justru ada pernyataan bahwa membersihkan bug adalah 60\% dari pekerjaan seorang programer. Semakin sedikit code program yang Anda tuliskan, semakin kecil keperluan agar code atau program maintainable. Semakin banyak code program yang Anda tuliskan, semakin perlu Anda memikirkan maintainabilitas program Anda.

\section{Usabilitas (Mudah Digunakan dan Sederhana dalam Pengoperasiannya)}

Layaknya seoseorang yang bingung ketika baru pertama kali datang ke Jakarta dan ingin mencari alamat Jl. Jend. Gatot Subroto 10. Orang tersebut pasti merasa bingung untuk mencari alamat tersebut. Dalam kondisi bingung, orang tersebut tentu akan memanfaatkan marka jalan sebagai penunjuk arah. Dapat dibayangkan apabila di jalan raya tidak disediakan rambu-rambu lalu lintas dan marka jalan, tentu orang akan tersesat dan tidak tahu ke mana arah yang akan dituju. Begitu pula dengan media pembelajaran, ketersediaan tooltip, help, icon, logo, tombol, dsb akan sangat membantu pengguna yang baru pertama kali menggunakan media tersebut. Desain dan tata letak navigasi sangat membantu 
pengguna untuk memanfaatkan media tersebut. Apabila terjadi kesalahan pada program (error) maka ditampilkan pesan dengan bahasa yang mudah dipahami oleh pengguna.

Konsistensi bentuk dan letak navigasi juga mempengaruhi kenyamanan pengguna ketika menghayati informasi yang tersirat dalam media pembelajaran. Dengan hanya melihat tampilan awal, pengguna dapat mengetahui kondisi program dan dapat menentukan aksi-aksi alternatif. Semua pilihan dan bahan tampak sehingga mudah dicari bilamana diperlukan tanpa mengganggu pengguna dengan informasi yang berlebihan. Pengguna juga dapat dengan sangat mudah menebak, memperkirakan bahkan menentukan relasi antara aksi dan hasil, antara kontrol-kontrol dan efek yang ditimbulkannya, antara status software dan apa yang tampak. 5 . Ketepatan Pemilihan Jenis

Aplikasi/Software/Tool untuk

Pengembangan Karya media pembelajaran dikembangkan dengan aplikasi dan perangkat yang tepat sesuai dengan kebutuhan pengembang. Contohnya adalah untuk membuat desain grafis, tentu harus menggunakan perangkat lunak pengolah grafis, dan bukan perangkat lunak (aplikasi) yang diciptakan untuk mengolah kata. Contoh lain, untuk membuat presentasi, akan lebih mudah dikembangkan dengan perangkat lunak untuk membuat presentasi. Demikian juga tentang pemanfaatan tool yang tepat dan lebih mudah dalam pembuatan animasi, simulasi, test, dan fitur-fitur yang lain.

6. Kompatibilitas (Media Pembelajaran Dapat Diinstalasi/Dijalankan di Berbagai Hardware dan Software yang Ada) Perkembangan software dan hardware sudah cukup banyak bervariasi, semakin tinggi spesifikasinya, semakin tinggi kecepatan prosesnya. Bila dulu kecepatan akses RAM paling tinggi $8 \mathrm{MB}$, saat ini kecepatannya berkali lipat hingga 1 GB, CD ROM yang dulu kecepatan bacanya paling tinggi $4 \mathrm{X}$ saat ini $\mathrm{CD}$ ROM sudah umum dan memiliki banyak fungsi dengan kapasitas kecepatan yang tinggi, seperti CD-RW dengan speed hingga 52X bahkan ada yang mampu membaca DVD, demikian juga dengan Software Aplikasi, bila dulu aplikasinya sederhana dan cukup panjang proses menjalankan berbagai aplikasi didalamnya, saat ini aplikasi sudah sangat indah dengan tampilan grafis yang baik dan animatif, dengan navigasi yang mudah dan cepat dalam proses menjalankan aplikasinya. Belajar akan lebih baik, jika setiap orang bisa bekerja dimanapun tanpa ada hambatan spesifikasi komputer dan software yang dipersyaratkan untuk menjalankannya, oleh karenanya hasil karya yang baik kendaknya dapat dijalankan diberbagai kondisi hardware dan sofware yang beragam, artinya bisa dijalankan didalam spesifikasi komputer yang paling rendah sekalipun, bisa dijalankan dengan Operating System dengan platform apapun dan versi manapun, mulai dari yang awal hingga yang terbaru, dan software 
yang tidak dibatasi oleh versi keluaran baik versi awal maupun versi yang terbaru.

\section{Pemaketan Program Media Pembelajaran}

Terpadu dan Mudah dalam Eksekusi

Media pembelajaran terpaket dengan baik.

Proses instalasi berjalan secara otomatis dengan menggunakan Autorun. Dengan sekali install, program langsung dapat digunakan tanpa perlu melakukan instalasi lain satu persatu (plugin, dsb) atau proses rebooting komputer.

Shorcut/icon secara otomatis muncul setelah proses instalasi dengan nama yang mudah diidentifikasi. Fitur untuk uninstall program disediakan untuk membantu pengguna apabila sudah tidak memerlukan program tersebut. Program dapat juga dikembangkan tanpa proses instalasi, artinya dengan satu klik semua berjalan dengan sendiri. Hal ini semakin memudahkan pengguna terutama untuk siswa-siswa yang kurang dalam mengenal komputer.

8. Dokumentasi Program Media Pembelajaran yang Lengkap "Gimana nih cara instalasinya? Kok nggak panduannya?” Pertanyaan ini muncul ketika media pembelajaran yang telah kita buat ternyata tidak dilengkapi dengan dokumentasi tentang cara instalasi dan cara penggunaan. Definisi rekayasa perangkat lunak menurut Ian Sommerville adalah: "Program komputer dan dokumentasi yang berhubungan"

Jadi tidak boleh dilupakan bahwa sebutan perangkat lunak itu tidak hanya untuk program komputer, tetapi juga termasuk dokumentasi dan konfigurasi data yang berhubungan yang diperlukan untuk membuat program beroperasi dengan benar. Dengan definisi ini otomatis keluaran (output) produksi perangkat lunak disamping program komputer juga dokumentasi lengkap berhubungan dengannya. Ini yang kadang kurang dipahami oleh pengembang, sehingga menganggap cukup memberikan program yang jalan (running program) ke pengguna.

Dokumentasi media pembelajaran yang dibuat harus meliputi: petunjuk instalasi (jelas, singkat, lengkap), trouble shooting (jelas, terstruktur, dan antisipatif), desain program (jelas, menggambarkan alur kerja program).

Dokumentasi, selain berorientasi ke kemudahan pengguna dengan adanya help, readme, panduan penggunaan, dsb, juga berorientasi pada pengembang yang diimplikasikan pada lengkapnya dokumentasi dan penjelasan pada kode program sehingga memudahkan dalam modifikasi.

9. Reusabilitas (Sebagian atau Seluruh Program Media Pembelajaran dapat Dimanfaatkan Kembali untuk Mengembangkan Media Pembelajaran Lain)

Eric S. Raymond, seorang tokoh programmer opensource mengatakan "Good programmers know what to write. Great ones know what to rewrite and reuse". Setelah level membuat terlewati, seorang pengembang harus 
meningkatkan kemampuan diri untuk tidak hanya berorientasi membuat, tapi juga berorientasi ke bagaimana fitur dan fungsi program kita supaya dapat digunakan lagi di program lain dengan mudah. Bagaimana kita mendesain sebuah source code (kode sumber), icon, logo, tombol dan sebagainya sehingga dengan mudah dapat digunakan kembali (reuse) pada program media pembelajaran lain, itulah arti dari reusabilitas.

Template menu, icon, logo, tombol, dsb yang telah dibuat dapat dengan mudah digunakan untuk program lain. Library (DLL, API, dsb) juga dikemas dengan baik sehingga dapat dimanfaatkan oleh program lain. Program tersusun secara modular, hal ini mempermudah penggunaan kembali (reusabilitas).

Konsep Manajemen Proyek

Manajemen proyek sistem informasi ditekankan pada tiga faktor, yaitu : manusia, masalah dan proses. Dalam pekerjaan sistem informasi faktor manusia sangat berperan penting dalam suksesnya manajemen proyek. Pentingnya faktor manusia dinyatakan dalam model kematangan kemampuan manajement manusia (a people management capability maturity model / PMCMM) yang berfungsi untuk meningkatkan kesiapan organisasi perangkat lunak (sistem informasi) dalam menyelesaikan masalah dengan melakukan kegiatan menerima, memilih, kinerja manajemen, pelatihan, kompensasi, pengembangan karier, organisasi dan rancangan kerja serta pengembangan tim. 
DAFTARPUSTAKA

[1]Kerka,S.,\&Wonacott,M.E.(2000).

Assessinglearnersonline:practitioner

file.Colombus:OhioStateUniversity

ERICClearingHouseonAdult, Career, and VocationalEducation Centeron

EducationandTrainingforEmployment.

[2]Kibby,M.(1999).Assessingstudent online. TheUniversityofNew Castle.

Retrieved from

http://www.newcastle.edu.au/departm ent/so/assess.htm

[3]Meyen, E.L.(2000). Usingtechnology to move research to practise:The OnlineAcademmy. TheirWorld 2000. NewYork:NationalCentreforLearning Disabilities.

[4] SWAP. (2004). Assessment. Retrievedfrom SWAP websiteprinted page:

www.swap/learning/assessment.asp [5]Webb,N.L.(1992).Assessmentof Student Knowledge of Mathematics: Step toward a Theory. University of WisconsinMadison.

[6] Wiggins, G. (1998). Educative assessment:designingassessmentsto reform andimprovegroupperformance. SanFrancisco:JosseyBass. 